\title{
THE EFFECT OF COMMENTARIES ABOUT ISLAMIC LAW ON SEMANTIC SHIFT OF QURANIC WORDS: SAÎ'D (صَعِيدٌ) EXAMPLE
}

İsmail Aydın*

* Muğla Sitk1 Koçman Ün. İlahiyat Fak. E-mail: ismailaydin@mu.edu.tr

Copyright (C) 2015 İsmail Aydın. This is an open access article distributed under the Eurasian Academy of Sciences License, which permits unrestricted use, distribution, and reproduction in any medium, provided the original work is properly cited.

\begin{abstract}
Words are the building blocks of the languages. The communication between people is only possible with some combination of these building blocks. Therefore words have very important functions in a healthy communication in a particular language. It is undeniable that the words have great importance in appreciating the meanings of the Quran which is the last massage to humanity. To know what god wants indeed is primarily depend on to understand correctly the words which belong to the language chosen to means of addressing, that is to say Arabic. Therefore to ascertain the meanings of words in the Quran enable us to understand the Quran better. Especially this is of great importance in translating the Quran into other languages.
\end{abstract}

Keywords: Quran, Jurisprudent, interpretation, saî’d, commentary.

\section{Fıkhî Yorumların Kur'an Lafızlarındaki Anlam Kaymalarına Etkisi ("Saî'd (صَبِيُّ)" Örneği)}

\section{ÖZET}

Kelimeler dillerin yapı taşlarıdır. İnsanlar arasındaki iletişim ancak bu yapı taşlarının çeşitli kombinasyonlarıyla gerçekleşmektedir. Dolayısıyla bir dilde sağlıklı iletişim kurmada kelimelerin son derece önemli işlevleri vardır. Son ilahi mesaj Kur'an'ın anlamlarını belirlemede de sözcüklerin başat role sahip oldukları yadsınamaz bir gerçektir. Allah'ın muradının belirlenmesi, her şeyden önce, hitap aracı olarak seçtiği dildeki kelimelerin doğru anlaşılmasına bağlıdır. Bu yüzden Kur'an'daki kelimelerin dil açısından anlamlarını tespit etmek Kur'ân'ın daha iyi anlaşılmasına imkân verecektir. Özellikle bu husus, Kur'an'ın başka dillere çevirilerinde daha büyük bir önem arz etmektedir.

Anahtar Kelimeler: Kur'an, F1kıh, meal, saî'd, yorum

I

Kur'an, en doğru yolu insanlara göstermek ve rehberliğiyle onların türlü problemlerini çözmek için indirilen bir kitaptır. ${ }^{1}$ Ancak onun bu misyonu yerine getirebilmesi her şeyden önce ihtiva ettiği

$1 \quad$ Bkz.: Bakara, 2/2; İsra, 17/9; Nisa, 4/59. 
anlamların keşfedilmesine bağlıdır. Aksi halde Kur'an'ın insanlara sunduğu hidayet mesajı sonuçsuz kalacaktır. Kur'an'ın anlamlarını doğru tespit etmenin ilk basamağı onun kelime ve kavramları üzerinde derin araştırmalar yapmaktır. Çünkü o, muhataplara nazil olduğu dilin kelime ve kavramlarıyla hitap etmiştir. Yani Kur'an'daki lafızlar, öncelikle hitap edilen toplumun zihnindeki anlamları karşılayacak şekilde nazil olmuştur. Meşhur nahiv âlimi Ebu'l-Hasen el-Ahfeş'in (ö. 215/930), "Kur'ân Arapların sözlerine delalet eder" 2 şeklindeki sözü, belirttiğimiz bu gerçeğin ifadesinden başka bir şey değildir. Bu söz, nüzul döneminde Araplar arasında cari olan dilin, sadece ilahî kelamın anlaşılmasında önemli unsurlardan biri olduğuna dikkat çekmemekte, aynı zamanda, Kur'an'ın anlamlarını belirleme eyleminde ilk basamağın kelimeler olduğuna işaret etmektedir. Elbette şu ana kadar anlatılanlardan, Kur'an'ın anlaşılmasında, onun içerdiği kelimelerin anlamlarını belirlemenin yeterli olacağı şeklinde bir hükme varılmamalıdır. Kur'an'ın anlamlarını belirlemede sadece kelimelerin delalet ettiği anlamları tespit etmek tek başına yeterli bir kriter olmasa da, bu amaca ulaşmada en önemli aşamalardan birinin bu olduğu göz ardı edilmemelidir. Bu hususun önemini vurgularken Râgib elİsfehânî (ö. 502/1108) şöyle der:

Kur'ân ilimlerinde meşgul olunması gereken ilk şey, lafzî ilimlerdir. Lafzî ilimlerde ise yapılması gereken şey, kelimelerin anlamlarını ortaya çıkarmaktır. Kur'ân'ın anlamlarına ulaşmak isteyen kişi için ilk yardımcı, lafızların anlamlarının belirlenmesidir. Bu, tıpkı bir binayı inşa etmek isteyen kişinin tuğlalarla işe başlaması gibidir. Üstelik bu husus sadece Kur'ân ilimleri açısından değil, tüm şer'î ilimler açından faydalıdır. ${ }^{3}$

Râgıb el-İsfehânî'nin sözünden anlaşıldığına göre, Kur'an ifadelerinin anlamını tespit etmek her şeyden önce kelimelerin manasını doğru olarak belirlemeye endekslidir. Aksi takdirde Kur'an'da hedeflenen anlamlara ulaşmak mümkün değildir. İşte bu çalışma, Kur'an'da yer alan "sai'd" (صعيد'da ) kelimesinin ilişkili olduğu esas anlamdan nasıl uzaklaştırıldığını göstermeyi ve Kur'an'ın doğru anlamlarına ulaşmak için onun ihtiva ettiği lafızların ince tetkikler gerektirdiği hususuna dikkat çekmeyi amaçlamaktadır. Çeşitli manalar barındıran bazı kelimelerin kişisel yorum sonucunda içerdiği esas anlamdan uzaklaştırılıp farklı bir anlamla bütünleştirilmesine en iyi örneklerden biri "saî'd" kelimesidir. Konuyu işlerken örnek olarak seçtiğimiz "saî'd" kelimesi Kur'an'da dört yerde geçmektedir. İlgili ayetler şunlardır:

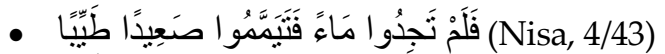

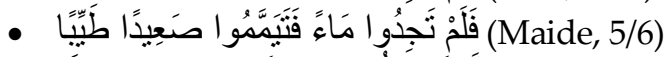

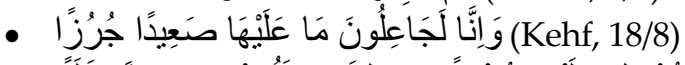

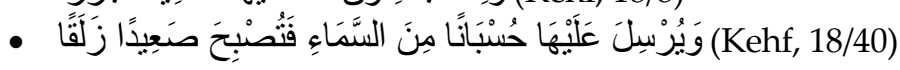

Bu çalışmada biz, "saî'd" kelimesinin fikhî bir içtihat sonucunda ait olduğu filolojik anlamla ilişkisinin nasıl zayıflatıldığını ve hatta ondan koparıldığını göstermeye çalışacağız. Bu bakımdan konuyu yukarıda zikredilen ayetlerden daha çok ilk ikisi, yani Nisa 4/43. ve Maide 5/6. ayetleri etrafında işlemeye gayret edeceğiz. Çünkü fıkhî yorumun söz konusu kelimenin farklı bir zemine kaymasıyla doğrudan ilişkili olan ayetler bunlardır.

\section{II}

Kur'an'da sâ̂'d kelimesinin kullanıldığı odak anlamı tespit ederken araştırmaya filolojik kaynaklardan başlamak elzemdir. Bu amaç doğrultusunda ilk sözlükler başlangıç noktamız olmalıdır. Dilcilerin bu kelimeye ilişkin verdikleri bilgilerin birincil referans alınması araştırmanın sağlıklı bir

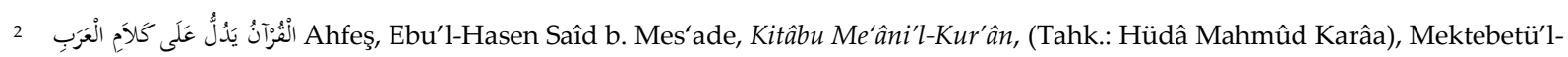
Hâncî, Kâhire, 1990, II, 561. Benzer yaklaşım için bkz.: Zeccâc, Ebû İshâk İbrâhîm b. es-Sirrî, Me'âni'l-Kur'ân ve I'râbuh, (Tahk.: Abdülcelîl Abduh Çelebî), Dâru'l-Hadîs, Kâhire, 2005, I, 266.

3 Râgib el-İsfehânî, el-Huseyn b. Muhammed b. el-Mufaddal, Müfredâtü Elfâzi'l-Kur'ân, (Tahk.: Safvân Adnân Dâvûdî), Dâru'lKalem, Dimeşk, 1992, s. 54. (Müellifin mukaddimesi) 
sonuca ulaşması bakımından önem arz etmektedir. Arapçanın ilk sözlüğünü yazan Halîl b. Ahmed (ö. 175/791); "Sâ̂'d -miktarı önemli olmaksızın- yeryüzü demektir"4 dedikten sonra bu anlamı desteklemek için aşağıdaki şiirle istişhad eder:

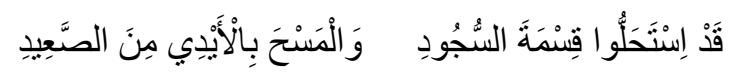

(Yolculukta) namazı kısaltmayı ve yeryüzüne elleri sürmeyi helal saydılar. ${ }^{5}$

Buna ilaveten Halîl b. Ahmed, Arapların "yere otur" anlamına gelen عَلَيْكَ بَالصََّعِيِد ifadesini kullandıklarını belirtir. ${ }^{6}$

İlk filolojik tefsirlerden biri olan, aynı zamanda garîbü'l-Kur'an türü eserler içinde yer alan Ebû Ubeyde'nin (ö. 210/825) Mecâzü'l-Kur'an isimli eserinde aynı şekilde "saî'd" kelimesi "yeryüzü" olarak tefsir edilmiştir.7 Garîbü'l-Kur'an müellifi İbnü'l-Yezîdî (ö. 237/851) ile Meşhur dilcilerden Ebû Cafer enNehhâs (ö. 338/949) gibi âlimler de "saî'd" kelimesinin -üzerinde toprak olsun veya olmasın- yeryüzü anlamına geldiğini söylemişlerdir. ${ }^{8}$ Bu kelimenin "yeryüzü" anlamına geldiğini söyleyenlerden biri de Kur'ân araştırmacılarının müstağni kalamadığı Müfredât isimli eserin müellifi- Râgib el-İsfehânî'dir. ${ }^{9}$ "Saî'd" kelimesinin "yeryüzü" anlamına geldiğini en açık şekilde vurgulayıp konuyla ilgili fikhî sonuçlara dikkat çeken dilci ve aynı zamanda müfessir olan Zeccâc'tır (ö. 311/923). O şöyle der:

“Saî'd kelimesi yeryüzü demektir. Teyemmümde insanın yapması gereken, iki eliyle bir vuruş gerçekleştirip bütün yüzünü mesh ettikten sonra bir vuruş daha yapıp iki kolunu mesh etmesidir. Ayetteki طَيِّيَّ kelimesi "temiz" anlamına gelir. Bunu yaparken kişi elini vurduğu yerde toprak olup olmamasına bakmaz. Çünkü الصَِّيَّ kelimesi 'toprak' demek değildir. Onun anlamı, toprak olsun ya da olmasın yeryüzü (وَجْهُ الأرْضِ) demektir. Eğer yerde hiç toprak olmazsa ve tamamen taş olsa teyemmüm eden kişi bu taşlara elini vursa ve yüzünü bununla mesh etse temizlenmiş olur. Sầ’d kelimesinin yeryüzü anlamına geldiğine dair dilciler arasında bir ihtilaf bilmemekteyim."10

Zemahşerî'nin (ö. 538/1143) sözü edilen kelimenin "yeryüzü" anlamına geldiğini söylerken Zeccâc'ın görüşünü nakletmekle yetinmesi ve -bir hanefî olarak da- Ebû Hanîfe'nin (ö. 150/767) de aynı görüşte olduğunu söylemesi kendisinin de aynı görüşü paylaştığı anlamına gelmektedir ${ }^{11}$

Diğer bir dilci Ebû Hayyân (ö. 745/1344) da Tuhfetü'l-Erîb isimli eserinde saî'd kelimesinin "yeryüzü" anlamına geldiğini beyan etmiştir. Bu bilgiler 1şığında söyleyecek olursak dilcilerin kaleme

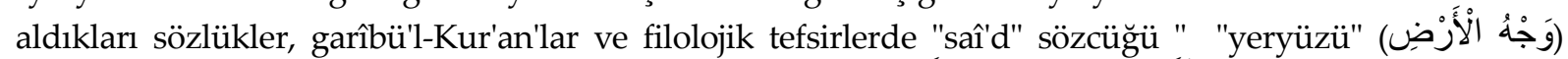

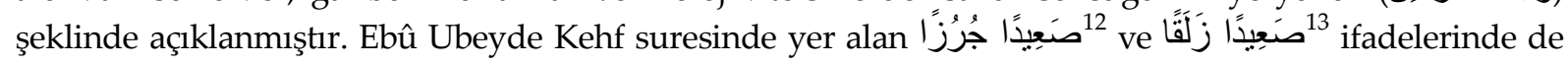
"saî'd" kelimesinin "yeryüzü" anlamına geldiğini belirtir. ${ }^{14}$ Dilcilerin sözü edilen lafızla ilgili dikkat çektikleri bu odak anlamın, önceden geliştirilen fıkhî yorumlarla yavaş yavaş farklı bir zemine kaymaya başlamıştır. Hicri üçüncü asrın sonlarından itibaren tefsir eserlerinde kelimeyle ilgili yer zikredilen anlamlar bunun açık bir göstergesidir. Ancak bu anlam kaymasının nedenlerinden biri aşağıda

4 Ferâhidî, Ebû Abdurrahmân Halîl b. Ahmed, Kitâbü'l-Ayn alâ Hurûfi'l-Mu'cem, (Trb. ve Tahk.: Abdülhamîd Hindâvî), Dâru'lKütübi'l-İlmiyye, Beyrût, 2003, II, 395.

5 Zü'r-Rumme, Divan, (Şerh: Ebû Nasr el-Bâhilî), (Tahk.: Abdülkuddûs Ebû Sâlih), Müessesetü'l-Îmân, Beyrût, 1982, I, 340.

6 Halîl b. Ahmed, Kitâbü'l-Ayn, II, 395.

Ebû Ubeyde, Ma'mer b. el-Müsennâ, Mecâzü'l-Kur'ân, (Tahk.: Fuâd Sezgîn), Mektebetü'l-Hâncî, Kâhire, ts., I, 128 ; I, 155.

8 İbnü'l-Yezîdî, Ebû Abdurrahmân Abdullâh b. Yahyâ b. el-Mübârek, Garîbu'l-Kur'ân ve Tefsîruh, (Tahk.: Abdürrezzâk Huseyn), Müessesetü'r-Risâle, Beyrût, 1987, s. 119; Nehhâs, Ebû Ca'fer Ahmed b. Muhammed b. İsmâîl, Me'âni'l-Kur'âni'lKerîm, (Tahk.: Muhammed Alî es-Sâbûnî), Merkezü İhyâi't-Türâsi'l-İslâmî, Mekke, 1988, I, 98.

9 Râgib el-İsfehânî, Müfredât, دeص mad.

10 Zeccâc, Me'âni'l-Kur'ân, II, 45.

11 Bkz.: Zemahşerî, Ebu'l-Kâsım Cârullâh Mahmûd b. Ömer b. Muhammed, el-Keşşâf an Hakâiki Gavâmidi't-Tenzîl ve Uyûni'lEkâvîl fî Vücûhi't-Te'vîll, (Nşr.: Muhammed Abdüsselâm Şâhîn), Dâru'l-Kütübi'l-ïlmiyye, Beyrût, 1995, I, 504.

12 Kehf, $18 / 8$

13 Kehf, $18 / 40$.

14 Ebû Ubeyde, Mecâzü'l-Kur'an, I, 393, 403. 
zikredileceği üzere Abdullâh İbn Abbâs'a nisbet edilen fikhî yorum ve bunu desteklemek için nakledilen bir hadistir.

Taberî (ö. 310/822), "saî'd"i açıklarken onun; "üzerinde ot ve ağaç olmayan düz yer", "toprak" ve "yeryüzü" anlamına geldiğine ilişkin üç görüşe yer verdikten sonra şöyle der: "Kelimeyle ilgili zikredilen bu manalardan en doğrusu, onun, "yeryüzü" anlamına geldiğini söyleyenlerin görüşüdür."15 Taberî'nin verdiği bu bilgiden ve ortaya koyduğu tercihten anladığımıza göre, "yeryüzü" dışında kelimeye izafe edilen diğer anlamlar aslında tarihi süreçte ortaya çıkan fikhî yorumun etkisiyle ona yamalanmıştır. Bu bakımdan Taberî'nin kendi tercihini fikhî yorumun etkisiyle ortaya çıkan anlamlardan değil de, filolojik anlamdan yana koyması dikkat çekicidir.

Benzer şekilde Ahkâmu'l-Kur'an müellifi İbn Arabî (ö. 543/1148), kelimeyle ilgili zikredilen dört farklı anlama işaret ederken onun "toprak" anlamına geldiğine ilişkin Abdullâh İbn Abbâs'ın görüşünü de zikreder. Bu arada onun Şafiî'nin de aynı görüşü tercih ettiğini belirtmesi, kelimenin uğradığı anlam kaymasının tarihi kökeni hakkında yeterince fikir vermektedir. Ancak İbn Arabî, iştikak kuralları ve dil açısından bu kelimenin gerçekte -ister taş, ister, kum isterse de toprak olsun- "yeryüzü" anlamına geldiğini eklemeyi gerekli görmüştür.

Yine İbn Atiyye (ö. 546/1151) ve Kurtubî (ö. 671/1272) gibi müfessirler, fikhî mezheplerin kelimeyi nasıl yorumladıklarına bağlı olarak teyemmümün ne ile yapılması gerektiğine dair ihtilafları işlerlerken dil açısından onun "yeryüzü" anlamına geldiğini belirtmekten geri durmamışlardır. ${ }^{16}$ Elmalılı da (ö. 1942) -her ne kadar tefsirinin meal kısmında kelimeye "toprak" diye anlam verse de- tefsir kısmında "saî'd" kelimesinin filolojik anlamına şöyle dikkat çeker: "Saî'd yeryüzü demektir ki, taşa toprağa şamildir. Binaenaleyh ele hiç toprak bulaşmasa bile bir taş ile teyemmüm caiz olur."17

\section{III}

Dilcilerin "saî'd" kelimesine ilişkin verdikleri bilgiler 1şı̆̆ında Türkçe telif edilen meallerde bu kelimesinin çevirilere nasıl yansıdığın tespit etmek yararlı olacaktır. Bu tespit, meal yazımında filolojik araştırmalara ne oranda değer verildiğine sadece ışık tutmakla kalmayacak, aynı zamanda, fıkıh kitaplarının ve de fikhî hükümlerin algılarımız üzerinde ne derece ciddi tesirler meydana getirdiklerini de göz önüne sermiş olacaktır.

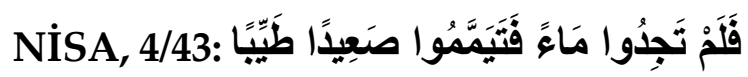

Elmalılı: "Suya güç yetiremezseniz o zaman temiz bir topră̆a teyemmüm edin."

H. Basri Çantay: "Su bulamazsanız o vakit temiz bir toprağa teyemmüm edin."

TDV (Heyet): "Su bulamamışsanız o zaman temiz bir toprakla teyemmüm edin."

S. Ateş: "Su bulamadığınız takdirde temiz toprağa teyemmüm edin."

M. Esed: Su bulamıorsanız, o zaman temiz toprağı alın ..."

M. Öztürk: "Su ya da suyu kullanma imkânı bulamamışsanız, o zaman temiz bir toprak arayın."

M. İslamoğlu: "Su da bulamıyorsanız, o zaman temiz bir toprak alıp ..."

Suat Yıldırım: "Su bulamazsanız, o vakit temiz topră̆a teyemmüm edin."

15 Taberî, Ebû Câ'fer Muhammed b. Cerîr, Câmiu'l-Beyân an Te'vîli Âyi'l-Kur'ân, (Tahk. Heyet) Dârü's-Selâm, , Kahire, 2009, III, 2347-2348.

16 İbn Atiyye, el-Kâdî Ebû Muhammed Abdülhak b. Gâlib, el-Muharrerü'l-Vecîz fî̀ Tefsîri'l-Kitâbi'l-Azîz, (Tahk.: Abdüsselâm Abdüşşâfî Muhammed), Dâru'l-Kütübi'l-İlmiyye, Beyrût, 2001, II, 59; Kurtubî, Ebû Abdullâh Muhammed b. Ahmed Ebû Bekr, el-Câmi' li Ahkâmi'l-Kur'ân ve'l-Mübeyyin limâ Tezammenehû mine's-Sünneti ve Âyi'l-Furkân, (Tahk.: Abdullâh b. Abdülhasen et-Türkî), Müessesetü'r-Risâle, Beyrût, 2006, VI, 390.

17 Elmalılı, Hamdi Yazır, Hak Dini Kur'an Dili, Merve Yayınları, İstanbul, 2011, III, 43. Benzer bir yaklaşım için bkz. Duman, Zeki, Beyânu'l-Hak, Fecr Yayınevi, Ankara, 2006, III, 241. 
Zeki Duman: "Su bulamamışsanız temiz bir yere dokunarak yüzünüzü ..."

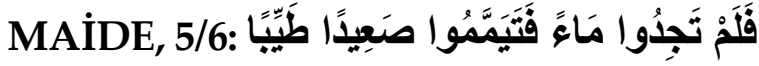

Elmalılı: "Suya gücünüz yetmezse, o vakit de temiz bir topră̆a teyemmüm edin."

H. Basri Çantay: "Su da bulamamışsanız o vakit tertemiz bir toprakla teyemmüm edin."

TDV (Heyet): "Su bulamamışsanız temiz toprakla teyemmüm edin."

S. Ateş: "Su bulamamışsanız temiz topră̆a teyemmüm edin."

M. Esed: Su bulamıyorsanız, o zaman temiz topră̆a ellerinizi sürün."

M. Öztürk: "Su ya da suyu kullanma imkânı bulamamışsanız, o zaman temiz bir toprak arayın.

M. İslamoğlu: "Su da bulamıyorsanız, o zaman temiz bir topră̆a yönelerek ..."

Suat Yıldırım: "Su bulamazsanız temiz topră̆a teyemmüm edin."

Zeki Duman: "Su bulamamışsanız temiz yer ile teyemmüm edin."

Yukarıda görüldüğü gibi incelediğimiz meallerin hemen tamamında "saî'd" kelimesi "toprak" olarak tercüme edilmiştir. Sadece Zeki Duman, ayet çevirilerinde kelimenin filolojik anlamına sadık bir çeviri yapan kişi olmuştur. Arapçada toprak anlamında kullanılan en yaygın kelimenin "türâb" (ثُرَابُ olduğu bu dili kullanan herkes tarafından -özellikle de Kur'an ilimleriyle meşgul olanlarca- bilinmektedir. Buna rağmen, Allah'ın, sözü edilen bu ayetlerde "türâb" yerine neden "saî'd" kelimesini kullandığına dair fikri bir muhakeme, meal yazarlarımızı ayetlerin doğru anlamlarına sevk etmesi için yeterli olabilirdi. Ayrıca şunu belirtmeliyiz ki, insanın yaratılışı söz konusu olduğunda Allah, devamlı "türab" kelimesini kullanmıştır. ${ }^{18} \mathrm{Bu}$ ayetlerin birinde bile "saî'd" kelimesinin yer almaması onun literal olarak toprak anlamına gelmediğinin bir emaresidir. Bu emareyi güçlendiren hususlardan biri de, İbn Kuteybe'nin Kehf suresinin sekizinci ayetinde yer alan "saî'd" kelimesiyle ilgili verdiği bilgidir. O şöyle der: "Sâ̂'d, yeryüzü demektir, yerin üstünü kapladı̆̆ından topră̆a da sâ̂’d denmiştir."19 Bir bakıma İbn Kuteybe (ö. 276/889), filolojik açıdan "saî'd" kelimesine "toprak" anlamının yüklenemeyeceğini, ancak yeryüzünün büyük bir kısmını kaplaması sebebiyle teşbih veya mecaz olarak onun bu kelimeyle nitelendirilmiş olduğunu söylemektedir.

Bu durum, Kur'an'daki lafızların gelişigüzel olarak değil, mükemmel bir sistem içerisinde kullanıldıklarını göstermektedir.

Unutmamak gerekir ki, Kur'an en genel anlamda araştırmayı ve kendi anlamları üzerinde tefekkür etmeyi emretmektedir. ${ }^{20}$

Dilcilerin kelimeyi "yeryüzü" olarak açıklayıp bu anlama vurgu yaptıkları halde, buna aykırı olarak onun "toprak" olarak çevrilmesi gerçekten ilginçtir. Bir kelimenin ait olduğu filolojik zeminden başka bir anlam zeminine kaymasının pek çok sebebi olabilir. Diğer bir ifadeyle dildeki bir lafzın anlamında daralma, genişleme veya tamamen dönüşme gibi bir takım değişiklikler bazı sebeplere bağlı olarak gerçekleşir. Bir canlıdaki hücreler gibi dillerin barındırdıkları kelimeler de devamlı yenilenme süreci içerisinde bulunurlar. Tarih sahnesinde beliren sosyal, siyasal, ekonomik vb. faktörler ve bunlar dışındaki her yeni gelişme dili de etkiler. Ancak Kur'an gibi dînî bir metinde yer alan bazı kelimelerin sahip oldukları anlamların, olması gerekenden farklı bir zemine kaymasının daha özel gerekçeleri de olabilmektedir. Bu aşamada bizim yapmamız gereken şey, örneklem olarak seçtiğimiz "saî'd" lafzının, filolojik anlamından uzaklaşmasının arka planına ışık tutmaktır.

\section{IV}

\footnotetext{
18 Bkz.: Âl-i İmrân, 3/59; Kehf, 18/37; Hacc, 22/5; Rum, 30/20; Fatır, 35/11; Gâfir, 40/67;

19 İbn Kuteybe, Ebû Muhammed Abdullâh b. Müslim, (ö. 276/889); Tefsîrü Garîbi'l-Kur'an, (Tahk.: Ahmed Sakr), elMektebetü'l-İlmiyye, Beyrut, 2007, 263.

20 Nisa, 4/94; Hucurat, 49/6; Kamer, 54/15, 17, 22, 32, 40; Nisa, 4/82; Muhammed, 47/24.
} 
Tarihi süreçte "saî'd" lafzının anlamı ile ilgili yanlış bir algının oluşmasının temelinde bazı rivayetlerin olduğu anlaşılmaktadır. Bu bağlamda Abdullâh İbn Abbâs'ın (ö. 68/687) teyemmüm edecek kişilere yönelik olarak, "yere ve onun toprağına yönelin"21 dediği nakledilir. Ayrıca kendisine sorulan آَيُ وَتِ

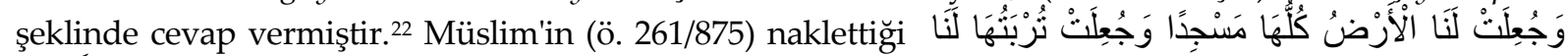
"Yerin tamamı bize mescid, toprağı da temiz(leyici) kılındı"23 şeklindeki hadis de teyemmümün toprakla yapılması gerektiğini savunanların referanslarından biri olmuştur.

"Saî'd" kelimesinin "yeryüzü" anlamından "toprak" anlamına taşınmasında İbn Abbâs'in teyemmüm ile ilgili yukarıdaki fıkhî içtihadının müessir bir rol oynadığını söyleyebiliriz. Kendisine yöneltilen soruya "saî'd" kelimesinin filolojik anlamına uygun bir cevap vermesi yerine, fikhî tercihini öne çıkararak yanıt vermesi, bazı âlimler nezdinde bu kelimenin toprak anlamına geldiğine ilişkin bir kanının oluşmasına sebep olmuştur. Daha sonra bu durum hatırı sayılır bazı fakihlerin aynı kanaati paylaşmasının sonucunda kelimenin "yeryüzü" şeklindeki filolojik anlamı tamamen perdelenmiştir. Bu fakihlerden biri olan Şafii'nin (ö. 204/819), "saî'd" kelimesinin bitki bitiren toprak anlamına geldiğini, dolayısıyla da onun dışındaki şeylerle teyemmüm etmenin caiz olmadığını söylerken zikri geçen rivayetlerden bağımsız hareket ettiğini düşünmek yanlıştır. ${ }^{24}$ Buna karşın kelimenin "yeryüzü" anlamına geldiğini kabul eden Ebû Hanîfe, teyemmüm için toprağı şart koşmamıştır. Bilindiği gibi fıkhî hükümlerin istinbat edilmesinde Kur'an'dan sonra en temel kaynak hadislerdir. Böyle olmakla birlikte zikredilen rivayetler, teyemmümün mutlaka toprak ile yapılması gerektiğine kesin şekilde delalet etmez. Çünkü hadisler, Kur'an gibi lafzen mütevatir olarak nakledilen bilgi kaynakları değildirler, bilakis onlar, genellikle mana ile rivayet edilmişlerdir. Bu yüzden dilcilerin çoğu ilave, eksiltme, tebdil, takdim ve tehir gibi hususların cari olması sebebiyle hadislerle istişhadtan kaçınmışlardır. Süfyân es-Sevrî'nin (ö. 161/777), "Ben size duyduğum şekilde söylüyorum dersem beni tasdik etmeyin. Bilakis size mana ile naklediyorum" 25 şeklindeki sözü de belirtilen durumu teyit etmektedir. Zikredilen hususlar dikkate alınacak olursa, sadece tek hadiste mevcut olan ve toprak anlamına gelen تُرَبَُّ lafzına bağlı olarak teyemmümün mutlak surette toprakla yapılması gerektiğine hükmetmek ayetin kapsamını daraltmak demektir. Ayrıca "yeryüzünün topră̆ı bize temiz(leyici) kılındi" ifadesinden "teyemmüm sadece toprakla olur" şeklinde mantıkî bir çıkarım elde etmek de mümkün değildir. Zaten tefsir eserlerinde yer alan farklı yorumlar ve ortaya çıkan ihtilaflar, teyemmümün mutlak olarak toprakla yapılması gerektiğine ilişkin bir kesinliğe imkân vermemektedir. Bu durumda lafzın filolojik anlamından sarf-1 nazar edip konuya ilişkin bir kaç rivayete dayalı olarak teyemmüm için toprağı şart koşmak, -her fırsatta- Kur'an'da vazedilen kolaylık ilkesine de aykırıdır. ${ }^{26}$

\section{V}

$\mathrm{Bu}$ araştırmada vardığımız sonuca göre, filolojik argümanları önceleyen tefsir kaynakları ve dilbilimsel eserlerin çoğu "saî'd" kelimesinin yeryüzü anlamına geldiğine ilişkin bir vurgu ihtiva etmektedirler. Buna karşın "saî'd" kelimesinin -dil ve tefsir eserlerine aykırı olarak- "meallerde" filolojik anlamının değil de, fıkhî yorumunun öne çıkması konuyla ilgili rivayetlerin etkisine bağlanabilir. Abdullah İbn Abbâs'in fıkhî yorumu ve yukarıda zikredilen hadis, lafzın filolojik anlamıyla ilgili

21 Vâhidî, Ebu'l-Hasen Alî b. Ahmed, el-Vasît fî Tefsîri'l-Kur'âni'l-Mecîd (Tahk.: Komisyon), Dâru'l-Kütübi'l-İlmiyye, Beyrût, 1994, II, 58.

22 İbn Ebî Hâtim, Abdurrahmân b. Muhammed b. İdrîs er-Râzî, Tefsîru'l-Kur'âni'l-Azîm Müsneden an Rasûlillâh ve's-Sahâbe ve'tTâbiîn, (Tahk.: Es'ad Muhammed et-Tayyib), Mektebetü Nizâri'l-Bâz, Mekke, 1997, III, 962; San'ânî, Ebû Bekr Abdürrezzâk b. Hemmâm, el-Musannef, (Tahk.: Habîbürrahmân el-A'zamî), Meclisü'l-İlmî, Beyrût, 1970, I, 211.

23 Müslim, Ebu'l-Huseyn b. el-Haccâc, el-Câmiu's-Sahîh, Çağrı Yayınları, İstanbul, 1992, Mesâcid, 4.

24 İmam Şafii, Ebû Abdullâh Muhammed b. İdrîs, el-Ümm, Beytü'l-Efkâr ed-Devliyye, Riyad, ts., s. 40. Ayrica bkz.: Kurtubî, elCâmi' li Ahkâmi'l-Kur'ân, VI, 391.

25 Zehebî, Ebû Abdullâh Şemsuddîn Muhammed b. Ahmed b. Osmân, Siyeru A'lâmi'n-Nübelâ, (Nşr.: Hassân Abdilmennân), Beytü'l-Efkâri'd-Devliyye, Yrs., ts., II, 1845.

26 Bkz.: Bakara, 2/185, 196. 
farkındalığın oluşmasını engellemiş ve ihtiva ettiği odak anlamı perdelemiştir. Ancak filolojik araştırmalara gereken değerin atfedilmemesi de bu yanılgının süregelmesinde önemli bir etki yaptığını göz ardı etmemek gerekir. Bu hususları maddeler şeklinde şöyle sıralayabiliriz:

- Meal yazarlarının, araştırmaya konu olan kelime ile ilgili filolojik araştırmalara yönelmemeleri.

- Önceki meallerde ve ilmihallerde konuya ilişkin bilgilere itimat edilmesi ve bu bilgilerin zihinleri şartlandırması.

- Klasik tefsirlerde konu ile ilgili bilgilerin dikkatten kaçması.

- Fıkhî hükümlerin kelimenin anlamının yanlış olarak algılanmasına sebep olması.

Kur'anî bir lafzın fikhî bir tercih sonucunda -amelî hayata etki edecek şekilde- filolojik anlamından uzaklaştırılmasına dair en çarpıcı örneklerden birini ele almış bulunmaktayız. Bir Kur'an okuyucusu, meallerden hareketle "saî'd" kelimesinin Arap dilindeki literal/lafzî karşılığının toprak olduğu sonucunu çıkarabilir. Hâlbuki bu araştırma kelimenin esas anlamının sanıldığı gibi olmadığını göstermektedir. Bu çalışma, aynı zamanda Kur'an'daki bir kelimenin/ayetin dirayet ve rivayet olgusuna bağlı olarak nasıl farklı iki anlama ve buna bağlı olarak değişik uygulamalara konu olabileceğini göstermesi bakımından da dikkat çekicidir. Bunun yanı sıra, üzerinde durulan konu, fikhî bir tercihe bağlı olarak Kur'anî bir lafzın filolojik anlamının nasıl ihmale uğradığının ve hatta unutulmaya yüz tuttuğunun en çarpıcı örneklerinden birini teşkil etmektedir. 


\section{REFERENCES}

- Ahfeş, Ebu'l-Hasen Saîd b. Mes‘ade (ö. 215/930); Kitâbu Me‘âni’l-Kur’ân, (Tahk.: Hüdâ Mahmûd Karâa), Mektebetü’l-Hâncî, Kâhire, 1990.

- Duman, Zeki, Beyânu'l-Hak, Fecr Yayınevi, Ankara, 2006.

- Ebû Hayyân, Esîruddîn Muhammed b. Yûsuf (ö. 745/1344); el-Bahru'l-Muhît, (Nşr.: Komisyon), Dâru'l-Kütübi'l-İlmiyye, Beyrût, 1993.

- Ebû Ubeyde, Ma‘mer b. el-Müsennâ (ö. 210/825); Mecâzü’l-Kur’ân, (Tahk.: Fuâd Sezgîn), Mektebetü'l-Hâncî, Kâhire, ts.

- Elmalılı, Hamdi Yazır (ö. 1942); Hak Dini Kur'an Dili, Merve Yayınları, İstanbul, 2011.

- Ferâhidî, Ebû Abdurrahmân Halîl b. Ahmed (ö. 175/791); Kitâbü’l-Ayn alâ Hurûfi’lMu'cem, (Trb. ve Tahk.: Abdülhamîd Hindâvî), Dâru’l-Kütübi’l-İlmiyye, Beyrût, 2003.

- İbn Atiyye, el-Kâdî Ebû Muhammed Abdülhak b. Gâlib (ö. 546/1151); elMuharrerü'l-Vecîz fî Tefsîri’l-Kitâbi’l-Azîz, (Tahk.: Abdüsselâm Abdüşşâfî Muhammed), Dâru'l-Kütübi’l-İlmiyye, Beyrût, 2001.

- İbn Düreyd, Ebû Bekr Muhammed b. el-Hasen el-Ezdî (ö. 321/933); Cemheretü’lLuga, (Nşr.: İ́brâhîm Şemseddîn), Dâru'l-Kütübi'l-İlmiyye, Beyrût, 2005.

- İbn Ebî Hâtim, Abdurrahmân b. Muhammed b. İdrîs er-Râzî (ö. 327/938); Tefsîru'lKur’âni’l-Azîm Müsneden an Rasûlillâh ve’s-Sahâbe ve’t-Tâbiîn, (Tahk.: Es‘ad Muhammed et-Tayyib), Mektebetü Nizâri'l-Bâz, Mekke, 1997.

- İbn Kuteybe, Ebû Muhammed Abdullâh b. Müslim, (ö. 276/889); Tefsîrü Garîbi'lKur'an, (Tahk.: Ahmed Sakr), el-Mektebetü'l-İlmiyye, Beyrut, 2007.

- İbnü'l-Arabî, Ebû Bekr Muhammed b. Abdullâh (ö. 543/1148); Ahkâmu'l-Kur’ân, (Nşr.: Muhammed Abdülkâdir Atâ), Dâru'l-Kütübi’l-İlmiyye, Beyrût, 2003.

- İbnü'l-Yezîdî, Ebû Abdurrahmân Abdullâh b. Yahyâ b. el-Mübârek (ö. 237/851); Garîbu'l-Kur’ân ve Tefsîruh, (Tahk.: Abdürrezzâk Huseyn), Müessesetü'r-Risâle, Beyrût, 1987.

- İmam Şafii, Ebû Abdullâh Muhammed b. İdrîs (ö. 204/819); el-Ümm, Beytü'l-Efkâr ed-Devliyye, Riyad, ts.

- Kurtubî, Ebû Abdullâh Muhammed b. Ahmed Ebû Bekr (ö. 671/1272); el-Câmi‘ li Ahkâmi'l-Kur'ân ve'l-Mübeyyin limâ Tezammenehû mine’s-Sünneti ve Âyi’l-Furkân, (Tahk.: Abdullâh b. Abdülhasen et-Türkî), Müessesetü’r-Risâle, Beyrût, 2006.

- Müslim, Ebu'l-Huseyn b. el-Haccâc (ö. 261/875); el-Câmiu's-Sahîh, Çağrı Yayınları, İstanbul, 1992.

- Nehhâs, Ebû Ca‘fer Ahmed b. Muhammed b. İsmâîl (ö. 338/949); Me‘âni’l-Kur’âni’lKerîm, (Tahk.: Muhammed Alî es-Sâbûnî), Merkezü İhyâi't-Türâsi’l-İslâmî, Mekke, 1988.

- Râgıb el-İsfehânî, el-Huseyn b. Muhammed b. el-Mufaddal (ö. 502/1108); Müfredâtü Elfâzi'l-Kur’ân, (Tahk.: Safvân Adnân Dâvûdî), Dâru'l-Kalem, Dimeşk, 1992.

- San'ânî, Ebû Bekr Abdürrezzâk b. Hemmâm (ö. 211/827), el-Musannef, (Tahk.: Habîbürrahmân el-A'zamî), Meclisü'l-İlmî, Beyrût, 1970.

- Taberî, Ebû Câ‘fer Muhammed b. Cerîr (ö. 310/922); Câmiu'l-Beyân an Te’vîli Âyi’lKur'ân, (Tahk. Heyet) Dârü's-Selâm, , Kahire, 2009.

- Vâhidî, Ebu'l-Hasen Alî b. Ahmed (ö. 468/1076); el-Vasît fî Tefsîri’l-Kur’âni’l-Mecîd (Tahk.: Komisyon), Dâru'l-Kütübi'l-İlmiyye, Beyrût, 1994. 
- Zâhidî, Senâullâh, Tevcîhü’l-Kârî ilâ'l-Kavâid ve'l-Fevâidi’l-Usûliyye ve'l-Hadîsiyye ve'l-İsnâdiyye fî Fethi'l-Bârî, Dâru'l-Fikr, Beyrût, 1993.

- Zeccâc, Ebû İshâk İbrâhîm b. es-Sirrî (ö. 311/923); Me‘âni’l-Kur'ân ve İ'râbuh, (Tahk.: Abdülcelîl Abduh Çelebî), Dâru’l-Hadîs, Kâhire, 2005.

- Zehebî, Ebû Abdullâh Şemsuddîn Muhammed b. Ahmed b. Osmân (ö. 748/1347); Siyeru A'lâmi'n-Nübelâ, (Nşr.: Hassân Abdilmennân), Beytü'l-Efkâri'd-Devliyye, Yrs., ts.

- Zemahşerî, Ebu'l-Kâsım Cârullâh Mahmûd b. Ömer b. Muhammed (ö. 538/1143); elKeşşâf an Hakâiki Gavâmidi't-Tenzîl ve Uyûni'l-Ekâvîl fî Vücûhi't-Te'vîl, (Nşr.: Muhammed Abdüsselâm Şâhîn), Dâru'l-Kütübi'l-İlmiyye, Beyrût, 1995.

- Zü'r-Rumme, Divan, (Şerh: Ebû Nasr el-Bâhilî) (ö. 177/793); (Tahk.: Abdülkuddûs Ebû Sâlih), Müessesetü'l-Îmân, Beyrût, 1982. 